\title{
The Impact Of Insider Trading On Market Liquidity In The NASDAQ Market
}

Walayet A. Khan, (E-mail: Wk3@evansville.edu), University of Evansville H. Kent Baker, (E-mail: kbaker@american.edu), American University Mukesh Chaudhry, (E-mail: Chaudhry@iup.edu), Indiana University of Pennsylvania Suneel K. Maheshwari, (E-mail: Maheshwari@Marshall.edu), Marshall University

\begin{abstract}
This study examines the relationship between insider trading and market liquidity (spread and depth) of NASDAQ-100 stocks. Tests on an intraday sample of sell trades show no evidence of cross-sectional association between the width of the spread and insider trading, but detect some widening of the spread after the fact. Overall, our results provide mixed evidence on the ability of NASDAQ dealers to unravel informed order flow and adjust spreads accordingly. Their shortterm behavior suggests an inability to detect insider trading and widen spreads, but their behavior over time suggests that dealers may attempt to recover what they apparently lose at a given point and time.
\end{abstract}

\section{INTRODUCTION}

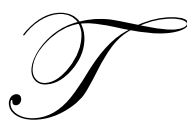

he interest in market microstructure is a growing phenomenon. In fact, Campbell, Lo, and MacKindlay (1997, pp. 83-84) state, "Indeed, market microstructure is now one of the most active research areas in economics and finance, spanning many markets and many models." Numerous market microstructure studies show that market arrangements affect market liquidity and asset returns. One important issue in market design involves the issue of whether trader anonymity - the extent to which a trader is recognized as informed or not - affects market liquidity as measured by bid/ask spreads. ${ }^{1}$

Although some trading models based on asymmetric information assume that markets are anonymous or that trader identity is unobservable, others do not. ${ }^{2}$ The assumption of anonymity may apply in some electronic systems, but it does not characterize other trading venues such as the NYSE specialist system. In fact, some exchange members claim that the professional relationships that evolve on exchange floors yield benefits that an anonymous exchange mechanism cannot easily duplicate. Thus, information-based models suggest that the impact of information on spread may differ between trading venues because of differences in the severity of information asymmetries.

Benveniste, Marcus, and Wilhelm (1992) argue that market makers in open-outcry environments such as the NYSE will likely react differently to insider trading than screen-based dealers such as NASDAQ. They contend that the unique relationship between specialists and floor brokers on the NYSE leads to less anonymity because specialists can learn information about traders' motives from floor brokers. Consequently, the behavior of specialists will differ depending on whether they perceive the trades as informed or uninformed. For example, the degree to which specialists are exposed to informed trading may affect the bid/ask spread. If specialists lose money when trading with individuals who possess superior information (informed traders such as insiders), they are likely to widen the spread to recover potential trading losses. Thus, a positive association should exist between the spread and the severity of information asymmetries confronted by specialists.

Benveniste, Marcus, and Wilhelm (1992) show that the benefits of a floor exchange mechanism are greatest when the potential for privately informed trading is greatest and when liquidity traders are most sensitive to 
transaction costs. This suggests that floor exchange mechanisms should yield their greatest benefits in markets for assets such as stocks and options where the potential for private information is greatest. They argue, however, that NASDAQ dealers will not behave differently based on informed and uninformed trades because they are unlikely to have information about trader type.

Prior studies examine the impact of information asymmetry on spread changes around important announcements such as stock repurchase, acquisition, dividends, earnings and insider holdings (see, for example, Conrad and Niden (1992), Lee, Muckrow, and Ready (1993), Foster and Viswanathan (1995), and Kini and Mian (1995)). A problem with these information events studies is that they use indirect and not completely satisfactory measures of the extent of information asymmetry. Several studies also present evidence that insiders reap positive abnormal returns (or avoid abnormal negative returns) when they trade their company shares because they presumably have access to private information and they act upon that information (see, for example, Lamba and Khan (1999) and Seyhun (1986)). ${ }^{3}$

Chung and Charoenwong (1998) use a direct measure of information asymmetry to investigate the effect of insider trades on spreads quoted by specialists in NYSE and AMEX listed stocks. The theory of information asymmetry predicts that specialists should widen their spreads when corporate insiders trade presumably because insiders trade on private information, i.e., they have superior knowledge compared with the specialists. Using information on insider trading during 1988, Chung and Charoenwong find a significant cross-sectional association between spread and insider trading, but no significant time series effects.

Garfinkel and Nimalendran (2003) focus on tests of relative anonymity by comparing specialist and dealer reactions to insider trading. Using a matched firms approach, they find that specialists are better able to discriminate between an informed and uninformed order flow compared to market makers on NASDAQ. Specifically, their results show that when corporate insiders trade medium-sized quantities (500-9,999 shares inclusive), NYSE listed stocks exhibit larger changes in proportional effective spreads than NASDAQ stocks. Their results support the hypothesis by Benveniste, Marcus, and Wilhelm (1992) that the unique relationship between specialists and floor brokers on the NYSE leads to less anonymity than on NASDAQ.

The purpose of our study is to examine the impact of insider trading on liquidity (spread and depth) in NASDAQ stocks. We assume that insiders are better informed than outsiders and that the motivations for their trades reflect private information. ${ }^{4}$ We test whether NASDAQ dealers can detect informed (insider) trading. If they can, we expect them to behave actively and alter their behavior on insider trades by widening of quoted spreads. Specifically, we examine the relation between quoted spreads and insider selling activity in NASDAQ-100 stocks during the period July through September 1998, a typical length for market microstructure studies We also examine changes in quoted depth from NASDAQ dealers in response to insider trading.

Our paper builds on the Chung and Charoenwong (1998) approach but examines the effect of insider trading on spreads quoted by dealers on NASDAQ, not by specialists in NYSE and AMEX listed stocks. For comparison purposes, we use a similar cross-sectional regression model as Chung and Charoenwong. ${ }^{5}$ Thus, our study of the impact of insider trading on market liquidity in NASDAQ complements that of Chung and Charoenwong involving similar effects on the NYSE and AMEX. Unlike Garfinkel and Nimalendran (2003), we do not test for differences in the reaction to insider trading across alternative market structures. That is, our concern is not whether a positive difference exists between specialist and dealer responses to insider trading. Because of different purposes and methodologies, the empirical results of these two studies are not directly comparable.

Our study contributes to the literature in several ways. First, few empirical studies focus on the quote response to information conveyed by insider trading. Our study fills a gap not covered by Chung and Charoenwong (1998) in that we examine a different market structure. Thus, we add to the limited evidence about how different market structures respond to informed trading. Second, we examine both spread and depth because together they give a better picture of market liquidity than spread alone. 
The remainder of the paper has the following organization. In the next section, we discuss the market microstructure differences between consolidated and the fragmented markets. We then explain our data, variables, and methodology followed by a presentation of our empirical results. In the final section, we present our conclusions.

\section{MARKET MICROSTRUCTURE DIFFERENCES AND INFORMATION FLOW}

The NYSE offers an open outcry auction trading environment that funnels order flow to one central place (the floor) where all the buy and sell orders are consolidated around the post of a single specialist. As agents for customers, brokers try to get the lowest possible price for the buy orders and the highest possible price for the sell orders. Price discovery occurs through the interaction of supply and demand of public order flow. The specialist in an assigned stock maintains a two-sided continuous market by offering bid and ask quotes and respective sizes (the number of shares of a stock the specialist is willing to buy at bid and sell at offer). The specialist continually adjusts quotes based on supply and demand trading sentiments in assigned stocks. Consolidated markets are informationally transparent because all activity takes place at one central location. This transparency makes specialists less vulnerable and better positioned to adjust the spread due to the arrival of informed order flow compared with market makers in markets with less anonymity.

Participants in an open outcry view all pit trading activity. Because market bids and offers are announced publicly, traders know who is making bids and offers. They know whether one or more traders are trying to hit the bid price or take the market offer. They also know whether a broker is filling a single customer order or many orders of small customers. Finally, they know whether outside orders or other traders, who are trying to balance their positions, are driving the market. Floor traders contend that pit information, floor intelligence, noise level, and eye contact provide them with valuable information about the arrival of incoming orders, market trends, and motives of other traders. Supposedly, this information flow helps them unveil superior information trading and adjust the spreads accordingly.

By contrast, NASDAQ offers relatively anonymous, screen-based trading in which geographically dispersed multiple dealers make markets in chosen stocks. Unlike floor trading, the entire order flow in a given stock is not consolidated at one central location but is fragmented across multiple dealers from many different locations. Fragmentation of order flow and information occurs on NASDAQ because of multiple dealers. Moreover, dispersed, computerized NASDAQ traders do not have exposure to the same information about the feel of the market or the motivations of potential counterparties that is available to traders who are face-to-face competing for order flow in an open outcry environment. By bringing trading from the pit into the firm's office, the traders lose valuable information obtained through personal contract.

Benveniste, Marcus, and Wilhelm (1992) contend that transparency offered by the open outcry system is valuable in uncovering informed trades. Although they do not contend that traders on the NYSE are perfectly transparent, they argue that NYSE specialists are more likely to receive any information about the identity of traders than are NASDAQ dealers. Consequently, NYSE specialists are more likely to handle adverse selection better than NASDAQ market makers are. In other words, they believe that the differences between the specialist structure on NYSE and the multiple market maker system on NASDAQ cause higher adverse selection on NASDAQ. This situation would occur when insiders are less anonymous on the NYSE than on the NASDAQ.

Yet, an opposing argument is that NASDAQ dealers can also deal with this adverse selection problem, but perhaps not as effectively as NYSE specialists can. The underlying logic of this argument goes as follows. NASDAQ dealers interact directly with brokers and can negotiate prices over the telephone with them. Exchange specialists communicate with broker's agents on the floor, but not directly with brokers. NASDAQ dealers maintain close contact with firms for which they make markets, but specialists do not have a similar relationship with listed firms. Through these relationships, NASDAQ dealers may be able to detect informed trading from insiders. Despite this potential type of information advantage over NYSE specialists, NASDAQ dealers face a substantial information disadvantage because of the fragmentation of order flow and anonymous electronic trading of NASDAQ. Thus, determining whether NASDAQ dealers can detect informed trading and adjust their market behavior accordingly is an empirical question. 


\section{DATA, VARIABLES, AND METHODOLOGY} methodology.

In this section, we review the sample, the measurement of the variables used in the study, and research

\section{Data}

We examine the NASDAQ-100 firms from July 1998 to September 1998. We obtain intra-day trades and quotes from the NYSE's TAQ database. Our sample consists of 485 sell transactions. Unlike Garfinkel and Nimalendran (2002), we study all types of insider trading for all trade sizes. We do not limit our examination to stealth (medium-sized) trades. Insider trading is a very small fraction of the overall volume for a day.

Table 1: Distribution of Insider Trading by Firm Size

This table reports the summary statistics of 485 sell transactions on NASDAQ-100 stocks traded from July through September 1998. The information is classified into four quartiles based on market value of equity from smallest (Q1) to largest (Q4).

\begin{tabular}{|c|c|c|c|c|c|}
\hline & Q1 & Q2 & Q3 & Q4 & All Firms \\
\hline Number of Firms & 25 & 25 & 25 & 25 & 100 \\
\hline Number of Insider transactions & 50 & 46 & 124 & 265 & 485 \\
\hline Average number of insider transactions per firm & 2.00 & 1.84 & 4.96 & 10.60 & 4.85 \\
\hline Average number of total transactions & 45,582 & 48,013 & 84,783 & 453,398 & 154,959 \\
\hline Percentage of insider trading & $0.004 \%$ & $0.004 \%$ & $0.006 \%$ & $0.002 \%$ & $0.003 \%$ \\
\hline Total value of insider transactions (in millions $\$$ ) & $\$ 33.13$ & $\$ 9.80$ & $\$ 16.65$ & $\$ 70.06$ & $\$ 129.65$ \\
\hline Median transaction size of insider trading & $\$ 2,366,452$ & $\$ 753,947$ & $\$ 1,387,408$ & $\$ 5,389,686$ & $\$ 2,493,201$ \\
\hline
\end{tabular}

Table 1 shows the summary statistics for our sample. We partition this table into quartiles (denoted by Q) by firm size as measured by the market value of equity. Table 1 shows that the average number of insider transactions increases by firm size from 2.00 transactions for the smallest group to 10.60 transactions for the largest group. The median transaction size of insider trading ranges from $\$ 753,947$ to $\$ 5,389,585$ for firms in Q2 and Q4, respectively. The size of these transactions is substantially larger than those observed by Chung and Charoenwong (1998) for NYSE listed stocks. The largest firms (Q4) account for more than half of the total insider transactions in term of number and value. Because the size and frequency of insider trading are larger in big firms, this may affect the information value of insider trades across different firm sizes.

\section{Measurement Of Variables}

Table 2 provides a summary of the variables used in the study. We measure insider trading in two ways, which are consistent with Chung and Charoenwong (1998). INS1 is the number of insider transactions. INS2 is the ratio of the number of insider transactions to the total number of transactions for the day. $(1992):^{6}$

The spread computation for stock $\mathrm{i}$ on day $\mathrm{t}\left(\mathrm{SPREAD}_{\mathrm{i}, \mathrm{t}}\right.$ ) follows the approach used by McInish and Wood

$\operatorname{SPREAD}_{\mathrm{i}, \mathrm{t}}=\sum_{\mathrm{k}}\left(\mathrm{D}_{\mathrm{k}} / \mathrm{L}\right)\left[\left(\mathrm{Ask}_{\mathrm{k}}-\mathrm{Bid}_{\mathrm{k}}\right) /\left\{\left(\mathrm{Ask}_{\mathrm{k}}+\mathrm{Bid}_{\mathrm{k}}\right) / 2\right\}\right]$

$\mathrm{D}_{\mathrm{k}} \quad=$ the duration of quotation $\mathrm{k}$ in seconds

$\mathrm{L}=$ the number of seconds for the trading day

$\mathrm{Ask}_{\mathrm{k}}$ and $\mathrm{Bid}_{\mathrm{k}}=$ ask and bid prices, respectively, of quotation $\mathrm{k}$, and $\mathrm{k}$ denotes the summation over $\mathrm{k}=1$ to $\theta$, where $\theta$ is the number of quotations for the day. 
Evidence by Benston and Hagerman (1974) and Stoll (1978) shows that riskier stocks are usually associated with larger spreads. We use the variance of intraday returns as a proxy for the risk (RISK) related to the stock.

We use average daily trade size (VOL) and number of transactions (NTS) as measures of trading activity. Studies by Benston and Hagerman (1974) as well as McInish and Wood (1992) document an inverse relationship between various measures of trading volume and spreads.

Following the definition used by McInish and Wood (1992) as well as Chung and Charoenwong (1998), we use abnormal trade size (ABTSIZE) to study the influence of information on spreads. The abnormal trade size is defined as the difference between the average daily trade size and average annual trade size of the stock. We include share price (PRICE) to control the effect of low-priced shares. Low-priced stocks tend to have relatively larger spread compared to high-priced stocks.

We measure firm size (MV) using the market value of the equity. We expect that smaller firms' stocks may exhibit greater spreads due to their low liquidity. Because firm size (MV) is correlated to variables such as PRICE and VOL, we introduce size into the cross-sectional regression model to segregate the correlation of firm size with spread from other variables.

Depth (DEPTH), another measure of market liquidity, represents size behind the reported quote for the bid and ask. Depth refers to the number of shares of a security that can be sold at the bid and ask prices near the market without causing a dramatic change in the price. Because greater depth suggests more liquidity, depth may reduce the spread. Chung and Charoenwong (1998) do not consider the impact of depth on spreads.

\section{Methodology}

We use both cross-sectional and pooled time series regressions to examine the impact of insider trading on market liquidity. We perform cross-sectional regression because the effect of certain variables on spread can be examined only in terms of their inter-stock differences. Regression using cross-sectional data should reveal whether dealers establish different spreads for different levels of insider trading. We use pooled time series regression to determine whether dealers make changes to quoted spread and depth when insiders trade. Our OLS results are based on White's (1980) correction for heteroscedasticity. ${ }^{7}$

\section{EMPIRICAL RESULTS}

In this section, we present the results of our cross-sectional and pooled time-series regression. To assess the impact of insider trading on market maker behavior, we examine the insider-trading day $\left(\mathrm{t}_{0}\right)$ and five days immediately before and after the insider-trading day. Thus, we analyze an 11-day event period. To avoid potentially confounding results, our final sample contains no insider trading for any firm during the 11-day event period window except on the event day $\left(\mathrm{t}_{0}\right)$. Table 3 presents information on spread, volume, and depth around the insider-trading day. The spread is lower on the insider-trading day than on surrounding days, possibly because other news raises spreads on the surrounding days. ${ }^{8}$ We observe that trading volume on the insider-trading day and two days before the insider-trading day is higher than trading volume after the insider-trading day. The depth of stocks on NASDAQ on and one day before the insider-trading day is higher than the other days in the event period. The abnormal trade size is also higher on and up to two days before the insider trade. This latter observation supports the view of Chung and Charoenwong (1998) that insiders may attempt to hide their trades by trading on high volume days.

The smaller spreads could be driven by differences in risk, volume, or other variables for which we have not adequately accounted. Theoretically, dealers should maintain wider spreads for stocks when they have information on insider trading. If this situation exists, we would expect spread to be positively related to insider trading in a crosssection of stocks. To evaluate whether dealers maintain a higher spread, we use the following cross-sectional regression model. 
Table 2: Descriptive Statistics

This table presents descriptive statistics of various firm characteristics and market microstructure variables for the stocks with insider trading on the day of that trade. SPREAD is the average spread of each stock for the period. INS1 is the number of insider transactions for each stock. INS2 is the ratio of the number of insider transactions to the total number of transactions. RISK is the variance of daily returns for each stock. NTS is the total number of transactions (trades). VOL is the average daily trade size for each stock. Price is the average price of each stock. MV is the market value of equity.

\begin{tabular}{|c|c|c|c|c|c|c|}
\hline \multicolumn{7}{|c|}{ Percentile } \\
\hline & Mean & $\begin{array}{c}\text { Standard } \\
\text { Deviation }\end{array}$ & 25 & 50 & 75 & 100 \\
\hline SPREAD & 0.1100 & 0.0300 & 0.0888 & 0.0989 & 0.1339 & 0.2115 \\
\hline INS1 & 1.4917 & 0.6568 & 1 & 1.2778 & 1.778 & 4.1667 \\
\hline INS2 & 0.0003 & 0.0001 & 0.0002 & 0.0003 & 0.0004 & 0.0004 \\
\hline RISK & $1.87 \times 10^{-6}$ & $2.78 \times 10^{-6}$ & $7.82 \times 10^{-7}$ & $1.12 \times 10^{-6}$ & $1.82 \times 10^{-6}$ & $2.4 \times 10^{-5}$ \\
\hline NTS & 3286 & 3276.53 & 885 & 2490 & 3946 & 19631 \\
\hline VOL & 1004.81 & 258.27 & 834.60 & 954.46 & 1074.16 & 2312.70 \\
\hline PRICE & 36.02 & 4.2323 & 33.55 & 36.71 & 39.46 & 42.90 \\
\hline MV (\$ million) & 2007 & 6705 & 2433 & 4099 & 9388 & 5548 \\
\hline
\end{tabular}

Table 3: Effects around the Insider-Trading Day

This table reports the average daily spread, volume, abnormal trade size, and depth during 11-day window including the insidertrading day $\left(\mathrm{t}_{0}\right)$ for NASDAQ-100 stocks (485 sell transactions) traded from July through September 1998.

\begin{tabular}{|c|c|c|c|c|c|c|c|}
\hline Day $^{1}$ & Spread $^{2}$ & $\%$ Spread $^{3}$ & $\begin{array}{c}\text { Total } \\
\text { Trading } \\
\text { Volume }\end{array}$ & $\begin{array}{c}\text { Insider } \\
\text { Trading } \\
\text { Volume }^{5}\end{array}$ & $\begin{array}{c}\text { Non-insider } \\
\text { trading } \\
\text { volume }^{6}\end{array}$ & $\begin{array}{l}\text { Abnormal } \\
\text { Trade size }^{7}\end{array}$ & Depth $^{8}$ \\
\hline-5 & 0.1322 & 0.0030 & 1149.53 & 0 & 1149.53 & 20.5220 & 3058.68 \\
\hline-4 & 0.1317 & 0.0029 & 1145.02 & 0 & 1145.02 & 16.2561 & 3049.86 \\
\hline-3 & 0.1340 & 0.0030 & 1111.43 & 0 & 1111.43 & -16.6630 & 3025.30 \\
\hline-2 & 0.1313 & 0.0029 & 1176.13 & 0 & 1176.13 & 47.5541 & 3056.33 \\
\hline-1 & 0.1286 & 0.0029 & 1183.49 & 0 & 1183.49 & 54.9153 & 3078.39 \\
\hline 0 & 0.1305 & 0.0029 & 1152.34 & 18.39 & 1134.95 & 24.4845 & 3050.40 \\
\hline 1 & 0.1334 & 0.0030 & 1134.16 & 0 & 1134.16 & 6.4464 & 2953.57 \\
\hline 2 & 0.1355 & 0.0031 & 1118.62 & 0 & 1118.62 & -10.2462 & 2929.01 \\
\hline 3 & 0.1374 & 0.0032 & 1111.04 & 0 & 1111.04 & -16.9501 & 2901.59 \\
\hline 4 & 0.1386 & 0.0032 & 1124.03 & 0 & 1124.03 & -3.6746 & 2994.48 \\
\hline 5 & 0.1377 & 0.0031 & 1114.52 & 0 & 1114.52 & -11.4040 & 2979.79 \\
\hline \multicolumn{8}{|c|}{$\begin{array}{l}{ }^{1} \text { Trading day relative to insider trading day } \\
{ }^{2} \text { The average daily spread } \\
{ }^{3} \text { The average daily spread in percentage } \\
{ }^{4} \text { The average daily trading volume (trade size) } \\
{ }^{5} \text { The average daily volume of insiders } \\
{ }^{6} \text { The average daily trading volume of non-insiders } \\
{ }^{7} \text { The average daily abnormal trade size } \\
{ }^{8} \text { The average daily depth (ask plus bid depth) }\end{array}$} \\
\hline
\end{tabular}

SPREAD $_{i}=\alpha_{0}+\alpha_{1}$ INS1 $_{i}\left(\operatorname{INS}_{\mathrm{i}}\right)+\alpha_{2}$ RISK $_{\mathrm{i}}+\alpha_{3} \mathrm{VOL}_{\mathrm{i}}+\alpha_{4} \mathrm{PRICE}_{\mathrm{i}}+\alpha_{5} \mathrm{MV}_{\mathrm{i}}+\varepsilon_{\mathrm{i}}$

To compare our results using cross-sectional regression to those of Chung and Charoenwong (1998), we exclude the variable ABTSIZE and DEPTH. 
Table 4: Cross-Sectional Regression Analysis

$$
\operatorname{SPREAD}_{\mathrm{i},}=\alpha_{0}+\alpha_{1} \operatorname{INS}_{\mathrm{i}}\left(\operatorname{INS}_{\mathrm{i}}\right)+\alpha_{2} \mathrm{RISK}_{\mathrm{i}}+\alpha_{3} \mathrm{VOL}_{\mathrm{i}}+\alpha_{4} \mathrm{PRICE}_{\mathrm{i}}+\alpha_{5} \mathrm{MV}_{\mathrm{i}}+\varepsilon_{\mathrm{t}}
$$

This table presents the results of the cross-sectional regression analysis. INS1 is the number of insider transactions for each stock. INS2 is the ratio of insider transactions to the total number of transactions for each stock. RISK is the variance of returns for each stock. VOL is the trading volume for each stock. PRICE is the average share price. MV is the market value of equity.

\begin{tabular}{|c|c|c|c|}
\hline \multicolumn{4}{|c|}{ Panel A: Using INS1 As An Insider-Trading Measure } \\
\hline & Model 1 & Model 2 & Model 3 \\
\hline \multirow[t]{2}{*}{ Intercept } & 0.1826 & 0.0978 & 0.0970 \\
\hline & $(18.44)^{*}$ & $(8.19)^{*}$ & $(7.51)^{*}$ \\
\hline \multirow[t]{2}{*}{ INS1 } & -0.0006 & -0.0011 & -0.0011 \\
\hline & $(-0.60)$ & $(-1.56)$ & $(-1.52)$ \\
\hline \multirow[t]{2}{*}{ RISK } & 591.1387 & 584.5620 & 586.8578 \\
\hline & $(2.88)^{*}$ & $(3.86)^{*}$ & $(3.84)^{*}$ \\
\hline \multirow[t]{2}{*}{ VOL } & $-1.30 \times 10^{-10}$ & $-2.40 \times 10^{-10}$ & $-2.36 \times 10^{-10}$ \\
\hline & $(-7.32)$ & $(-8.96)^{*}$ & $(-6.40)^{*}$ \\
\hline \multirow[t]{2}{*}{ PRICE } & & 0.0023 & 0.0026 \\
\hline & & $(8.23 *)$ & $(8.66)^{*}$ \\
\hline \multirow[t]{2}{*}{ MV } & & & $-2.12 \times 10^{-14}$ \\
\hline & & & $(-1.81)$ \\
\hline $\operatorname{Adj} R^{2}$ & 0.2458 & 0.5890 & 0.5847 \\
\hline \multirow[t]{2}{*}{ F-stat } & 11.648 & 36.115 & 28.599 \\
\hline & anel B: Using & ler-Trading Me & \\
\hline \multirow{2}{*}{ Intercept } & 0.1773 & 0.0961 & 0.0944 \\
\hline & $(16.24)^{*}$ & $(7.75)^{*}$ & $(7.08)^{*}$ \\
\hline \multirow[t]{2}{*}{ INS2 } & 50.1912 & -1.2529 & -0.6456 \\
\hline & $(0.69)$ & $(-0.02)$ & $(-0.02)$ \\
\hline \multirow[t]{2}{*}{ RISK } & 620.9112 & 602.8027 & 607.2369 \\
\hline & $(3.01)^{*}$ & $(3.90)^{*}$ & $(3.90)^{*}$ \\
\hline \multirow[t]{2}{*}{ VOL } & $-1.36 \times 10^{-10}$ & $-2.5588 \times 10^{-10}$ & $-2.4741 \times 10^{-10}$ \\
\hline & $(-4.25)^{*}$ & $(-9.28)^{*}$ & $(-6.66)^{*}$ \\
\hline \multirow[t]{2}{*}{ PRICE } & & 0.0025 & 0.0025 \\
\hline & & $(8.70)^{*}$ & $(8.45)^{*}$ \\
\hline \multirow[t]{2}{*}{ MV } & & & $-4.3163 \times 10^{-14}$ \\
\hline & & & $(-1.92)$ \\
\hline Adj R2 & 0.2468 & 0.5784 & 0.5744 \\
\hline F-stat & 11.701 & 34.618 & 27.457 \\
\hline
\end{tabular}

Panel A of Table 4 reports the results of a cross-sectional regression analysis using INS1 (the number of insider transactions) as the measure of insider trading. The first regression model shows the results when including only insider trading, risk, and volume. Models 2 and 3 show the results by adding share price and market value. Insider trading as measured by INS1 is not statistically significant under all three models. The results show that insider trading does not affect the spreads in NASDAQ. By contrast, Chung and Charoenwong (1998) report a significant cross-sectional association between spread and insider trading for NYSE and AMEX listed stocks.

Because the estimated coefficients for INS1 for all three models are similar in magnitude, multicollinearity is unlikely to affect the results in any significant manner. However, other events contemporaneous with insider trades may help to explain the lack of significant relationship between insider trading and spread behavior.

The estimated coefficients of other variables (RISK, VOL, PRICE) are statistically significant. These results are consistent with those presented in previous studies. The volume variable is significant in all three models. Adding market value in Model 3 does not increase the value of adjusted $R^{2}$. Overall, Models 2 and 3 explain about $58 \%$ of the cross-sectional variation in spreads. 
Table 5: Pooled Time-Series Regression

\begin{abstract}
SPREAD $_{\mathrm{t},}=\beta_{0}+\beta_{1} \mathrm{INS1}_{\mathrm{t}}\left(\mathrm{INS}_{\mathrm{t}}\right)+\beta_{2}$ RISK $_{\mathrm{t}}+\beta_{3}$ VOL $_{\mathrm{t}}+\beta_{4}$ PRICE $_{\mathrm{t}}+\beta_{5}$ ABTSIZE $_{\mathrm{t}}+\beta_{6}$ DEPTH $_{\mathrm{t}}+\varepsilon_{\mathrm{t}}$
This table presents the results of the pooled time-series regression analysis. INS1 is the number of net insider transactions for each stock. INS2 is the ratio of insider transactions to the total number of transactions for each stock. RISK is the variance of returns for each stock. VOL is the trading volume for each stock. PRICE is the average share price. ABTSIZE is the abnormal volume for each stock. DEPTH is to the number of shares of a security that can be sold at the bid and ask prices near the market without causing a dramatic change in the price.
\end{abstract}

\begin{tabular}{|c|c|c|c|c|}
\hline \multicolumn{5}{|c|}{ Panel A } \\
\hline & Model 1 & t-stats & Model 2 & t-stats \\
\hline Intercept & 0.1216 & $62.16^{*}$ & 0.1218 & $62.08 *$ \\
\hline INS1(1) & 0.0126 & $5.84 *$ & 5.4342 & $2.63^{*}$ \\
\hline RISK & 15.0199 & $4.59 *$ & 15.0819 & $4.60 *$ \\
\hline VOL & $-1.16 \times 10^{-8}$ & $-46.51 *$ & $-1.17 \times 10^{-8}$ & $-47.12 *$ \\
\hline PRICE & 0.0018 & $40.96^{*}$ & 0.0018 & $40.66^{*}$ \\
\hline ABTSIZE & $-1.60 \times 10^{-5}$ & $-7.11 *$ & $-1.61 \times 10^{-5}$ & $-7.14 *$ \\
\hline Adj $R^{2}$ & 0.3233 & & 0.3204 & \\
\hline F-Value & 606.185 & & 598.199 & \\
\hline \multicolumn{5}{|c|}{ Panel B } \\
\hline & Model 1 & t-stats & Model 2 & t-stats \\
\hline Intercept & 0.1917 & $53.38 *$ & 0.1923 & $53.42 *$ \\
\hline INS1(2) & 0.0118 & $5.66^{*}$ & 5.6972 & $2.87 *$ \\
\hline RISK & 14.7818 & $4.70 *$ & 14.8306 & $4.71 *$ \\
\hline VOL & $-6.3934 \times 10^{-9}$ & $19.40 *$ & $-6.5098 \times 10^{-9}$ & $19.73 *$ \\
\hline PRICE & 0.0014 & $28.99 *$ & 0.0014 & $28.72 *$ \\
\hline ABTSIZE & $1.2894 \times 10^{-5}$ & $5.94 *$ & $-1.2972 \times 10^{-5}$ & $5.96^{*}$ \\
\hline Depth & $-2.321 \times 10^{-5}$ & $22.92 *$ & $2.3330 \times 10^{-5}$ & $22.99 *$ \\
\hline $\operatorname{Adj} R^{2}$ & 0.3750 & & 0.3727 & \\
\hline F-Value & 634.523 & & 628.222 & \\
\hline
\end{tabular}

* Significance at the $5 \%$ level

Previous studies show that the market may respond to insider trading when it is significant in relation to total trading. To consider the effect of insider trading on spreads, Panel B of Table 4 uses INS2, which is the ratio of net insider transactions to total transactions. The results in Panel B are consistent with those reported in Panel A, confirming that insider trading does not have a significant impact on spread quoted by dealers in our sample of NASDAQ stocks. All other control variables are significant and the regression model explains up to $57 \%$ of the crosssectional variation in spreads. From the cross-sectional regression results, we do not find any significant relationship between the proportions of insider trading and spread. These results suggest that the information disadvantage due to anonymous trading and fragmentation of order flow across different NASDAQ dealers at a given point in time outweighs any information advantage NASDAQ dealers may have due to their ability to maintain close contacts with brokers and firms. Based on this evidence, NASDAQ dealers appear unable to detect and respond to informed order flow.

Table 5 presents the pooled time-series regression results of the number of net insider transactions on the quoted spread. We use the following model for the contemporaneous period:

$\operatorname{SPREAD}_{\mathrm{t}}=\beta_{0}+\beta_{1} \mathrm{INS1}_{\mathrm{t}}\left(\mathrm{INS}_{\mathrm{t}}\right)+\beta_{2} \mathrm{RISK}_{\mathrm{t}}+\beta_{3} \mathrm{VOL}_{\mathrm{t}}+\beta_{4}$ PRICE $_{\mathrm{t}}+\beta_{5}$ ABTSIZE $_{\mathrm{t}}+\beta_{6} \mathrm{DEPTH}_{\mathrm{t}}+\varepsilon_{\mathrm{t}}$

Panel A of Table 5 shows the results for Model 1, which are based on the number of insider transactions (INS1) as the measure of insider trading. Panel A also shows the results for Model 2, which uses INS2 (ratio of net insider transactions to total transactions) as the measure of insider trading. The coefficients for both measures are positive and in the predicted direction. After controlling for the effect of other variables (RISK, VOL, ABTSIZE, PRICE), the association between insider trading and spread is statistically significant. The regression models in Panel A do not control for depth. 
In addition to the control variables used in Panel A, the models used in Panel B also control for depth. The results suggest that INS1 and INS2 have a significant impact on the spread. Again, the coefficients are positive and in the predicted direction. All other variables are significant in both the models. The significance of abnormal trade size suggests that NASDAQ dealers react to large transactions and adjust spreads. DEPTH helps to explain the spread in the stocks. These results suggest that the measures of insider trading (INS1 and INS2) and DEPTH are important in explaining the variation in spread.

Taken in isolation, these results suggest that over time NASDAQ dealers may be able to unravel at least some of the informed order flow and adjust spreads accordingly. Thus, NASDAQ dealers may attempt to recover over time what they apparently lose at a given point in time to the informed order flow. A possible implication of these results is that dealers require time for any informational advantage associated with maintaining a close contact with brokers and firms to counteract their informational disadvantage of operating in a fragmented and relatively anonymous trading environment.

\section{CONCLUSIONS}

Based on our evidence, we can draw several tentative conclusions about the impact of insider trading on market liquidity in NASDAQ. On one hand, we find that spreads are lower on the insider-trading day than on surrounding days. This evidence conflicts with the hypothesis that NASDAQ dealers alter their behavior on insider trades by widening quoted spreads. We also find no evidence of a cross-sectional association between spreads and insider trading. An implication of these combined findings is that NASDAQ dealers are unaware of the presence of insiders and may lose money to them that is unrecoverable.

On the other hand, we document statistically significant pooled time-series effects of insider trading on spreads. The time-series results provide a way of viewing how dealers respond to insider trading that considers a time dimension. An implication of this finding is that dealers make intertemporal adjustments to the spreads when insiders trade.

By contrast, Chung and Charoenwong (1998) find evidence of cross-sectional association between spreads and insider trading but no time series association between these variables in the NYSE and AMEX specialist market. Such differences in results from our study may stem from differences in market microstructure arrangements such as the degree of anonymity reported by Benveniste, Marcus, and Wilhelm (1992) and documented by Garfinkel and Nimalendran (2003).

Taken as a whole, our results provide mixed evidence on the ability of NASDAQ dealers to unravel informed order flow and adjust spreads accordingly. Their short-term behavior suggests an inability to detect insider trading and widen spreads, but their behavior over time suggests that dealers attempt to recover what they apparently lose at a given point and time.

\section{SUGGESTIONS FOR FUTURE RESEARCH}

Researchers could modify or extend research on the relationship between insider trading and market liquidity in several ways. First, they could increase the size and duration of the sample. Our sample consists of 485 sell transactions over a limited period. Second, researchers could use effective spreads, instead of daily quoted spreads, to measure the reaction to insider trading. Third, they could use alternative approaches such as concentrating on the price impact of medium size sell orders on insider trading days and comparing them to an average day. Finally, researchers could compare specialist and dealer reactions to insider trading using the methodology in our paper as opposed to that used by Garfinkel and Nimalendran (2003). Control variables could be used, similar to those specified by Chung and Charoenwong (1998), to control for major differences in the firms on the different markets.

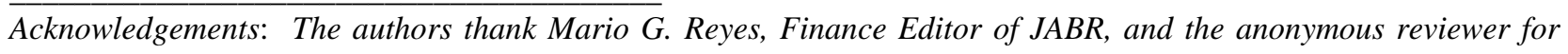
helpful suggestions. 


\section{ENDNOTES}

1. See, for example, O'Hara (1995) for a discussion of market microstructure theory involving informationbased models.

2. For example, information-based models by Glosten and Milgrom (1985) and Easley and O'Hara (1987) assume trader identity is unknown, whereas models by Admati and Pfleider (1991) and Forster and George (1992) allow for some trader transparency.

3. For effects of legal insider trading surrounding various events, see Netter and Mitchell (1989), Eyssell (1991), Karpoff and Lee (1991), Liu, Smith, and Syed (1992), Eyssell and Arshadi (1993), Eyssell and Reburn (1993), Chowdhury, Howe, and Lin (1993), Bebchuk and Fershtman (1994), Sivakumar and Waymire (1994), Ferreira (1995), Hanson and Song (1995), Pettitt and Vankatesh (1995), Raad and Wu (1995), Johnson, Serrano, and Tompson (1996), and Khan and Lamba (2001). For effects of illegal insider trading activity, see Chakravarty and McConnell (1997).

4. In practice, insiders may have various motives for trading, such as for liquidity reasons. Thus, information that dealers elicit through their relationships with brokers and firms may only provide a noisy signal of the insider's motive.

5. Unlike the cross-sectional regression analysis conducted by Chung and Charoenwong (1998), we exclude two independent variables: (1) a dummy variable representing the NYSE listing and (2) a variable representing the number of exchanges on which a stock is listed. Both variables have little, if any, meaning for our study involving NASDAQ.

6. Quoted spreads do not take into account market maker efforts to "price improve" on orders, which could affect measures of liquidity. Garfinkel and Nimalendran (2002) favor effective spreads but form similar conclusions about relative anonymity on the NYSE and NASDAQ whether they investigate changes in quoted spreads or effective spreads. That is, they find evidence that is consistent with less anonymity on the NYSE specialist system compared to the NASDAQ dealer system.

7. For a detailed discussion of tests and corrections for heteroskedasticity (including White's test and correction), see White (1980) and Greene (1993).

8. T-tests for differences in means show that the spread on the event day $\left(\mathrm{t}_{0}\right)$ differs significantly at the $5 \%$ level from the spread for each of the surrounding days. These results are available from the authors upon request.

9. The possibility exists that dealers can detect insider trades to sell, and lower both bid and ask prices in response. This will leave the spread unaffected.

\section{REFERENCES}

1. Admati, Anat R. and Paul Pfleiderer, Sunshine Trading and Financial Market Equilibrium, Review of Financial Studies, Vol. 4, No. 3, pp. 443-481, 1991.

2. Bebchuk, Lucian Arye and Chaim Fershtman, Insider Trading and the Managerial Choice Among Risky Projects, Journal of Financial and Quantitative Analysis, Vol. 29, No. 1, pp. 1-14, 1994.

3. Benston, George J. and Robert L. Hagerman, Determinants of Bid-Ask Spreads in the Over-the-Counter Market, Journal of Financial Economics, Vol. 1, No. 4, pp. 353-364, 1974.

4. Benveniste, Lawrence M., Alan J. Marcus, and William J. Wilhelm, What's Special about the Specialist? Journal of Financial Economics, Vol. 32, No. 1, pp. 61-86, 1992.

5. Campbell, John Y., Andrew W. Lo, and A. Craig MacKinlay, The Econometrics of Financial Markets, Princeton University Press, Princeton, New Jersey, 1997.

6. Chakravarty, Sugato and John J. McConnell, An Analysis of Prices, Bid/Ask Spreads, and Bid and Ask Depths Surrounding Ivan Boesky's Illegal Trading in Carnation's Stock, Financial Management, Vol. 26, No. 2, pp. 18-34, 1997.

7. Chowdhury, Mustafa, John S. Howe, and Ji-Chai Lin, The Relation Between Aggregate Insider Transactions and Stock Market Returns, Journal of Financial and Quantitative Analysis, Vol. 28, No. 3, pp. 431-437, 1993.

8. Chung, Kee H. and Charlie Charoenwong, Insider Trading and the Bid-Ask Spread, Financial Review, Vol. 33, No. 3, pp. 1-20, 1998.

9. Conrad, Jennifer and Cathy M. Niden, Order Flow, Trading Costs and Corporate Acquisition 
Announcements, Financial Management, Vol. 21, No. 4, pp. 22-31, 1992.

10. Easley, David and Maureen O'Hara, Price, Trade Size, and Information in Securities Markets, Journal of Financial Economics, Vol. 19, No. 1, pp. 69-90, 1987.

11. Eyssell, Thomas H., Corporate Insiders and the Death of the Firm: Evidence on the Incidence of Insider Trading in Corporate Dissolutions, Financial Review, Vol. 26, No. 4, pp. 517-534, 1991.

12. Eyssell, Thomas H. and Nasser Arshadi, Insiders, Outsiders, or Trend Chasers? An Investigation of PreTakeover Transactions in the Shares of Target Firms, Journal of Financial Research, Vol. 16, No. 1, pp. 4959, 1993.

13. Eyssell, Thomas H. and James P. Reburn, The Effects of the Insider Trading Sanctions Act of 1984: The Case of Seasoned Equity Offerings, Journal of Financial Research, Vol. 16, No. 2, pp. 161-170, 1993.

14. Ferreira, Eurico J., Insider Trading Activity, Different Market Regimes, and Abnormal Returns, Financial Review, Vol. 30, No. 2, pp.193-210, 1995.

15. Forster, Margaret M. and Thomas J. George, Anonymity in Securities Markets, Journal of Financial Intermediation, Vol. 2, No. 2, pp. 168-206, 1992.

16. Foster, F. Douglas, and S. Viswanathan, Trading Costs of Target Firms Around Corporate Takeovers, Advances in Financial Economics, Vol. 1, No. 1, pp. 37-58, 1995.

17. Garfinkel, Jon A., New Evidence on the Effects of Federal Regulations on insider Trading: The Insider Trading and Securities Fraud Enforcement Act (ITSFEA), Journal of Corporate Finance, Vol. 3, No. 2, pp. 89-111, 1997.

18. Garfinkel, Jon A. and M. Nimalendran, Market Structure and Trader Anonymity: An Analysis of Insider Trading, Journal of Financial and Quantitative Analysis, Vol. 38, No. 3, pp. 591-610, 2003.

19. Glosten, Lawrence R. and Paul R. Milgrom, Bid, Ask and Transaction Prices in a Specialist Market with Heterogeneously Informed Traders, Journal of Financial Economics, Vol. 14, No. 1, pp. 71-100, 1985.

20. Greene, William H., Econometric Analysis, $2^{\text {nd }}$, MacMillan, New York, 1993.

21. Guo, Enyang, Nilanjan Sen, and Dilip Shome, Analysts’ Forecasts: Low-Balling, Market Efficiency, and Insider Trading, Financial Review, Vol. 30, No. 3, pp. 529-539, 1995.

22. Hanson, Robert C. and Moon H. Song, Managerial Ownership Change and Firm Value: Evidence From Dual-Class Recapitalizations and Insider Trading, Journal of Financial Research, Vol. 18, No. 3, pp. 281297, 1995.

23. Johnson, Dana J., Jan M. Serrano, and G. Rodney Thompson, Seasoned Equity Offerings for New Investment and the Information Content of Insider Trades, Journal of Financial Research, Vol. 19, No. 1, pp. 91-103, 1996.

24. Karpoff, Jonathan M. and Daniel Lee, Insider Trading Before New Issue Announcements, Financial Management, Vol. 20, No. 1, pp. 18-26, 1991.

25. Khan, Walayet and Asjeet Lamba, The Effectiveness of Legal Sanctions in Curtailing Insider Trading: Evidence From Exchange Listings, Quarterly Journal of Business and Economics, Vol. 4, No. 1, pp. 3-15, 2001.

26. Kini, Omesh and Shehzad Mian, Bid-ask Spread and Ownership Structure, Journal of Financial Research, Vol. 18, No. 4, pp. 401-414, 1995.

27. Lamba, Asjeet and Walayet Khan, Exchange Listings and Delistings: The Role of Insider Information and Insider Trading, Journal of Financial Research, Vol. 22, No. 2, pp. 131-146, 1999.

28. Lee, Charles M. C., Belinda Muckrow, and Mark J. Ready, Spreads, Depths, and the Impact of Earnings Information: an Intraday Analysis, Review of Financial Studies, Vol. 6, No. 2, pp. 345-374, 1993.

29. Liu, Pu, Stanley D. Smith, and Azmat A. Syed, The Impact of the Insider Trading Scandal on the Information Content of the Wall Street Journal's Heard on the Street Column, Journal of Financial Research, Vol. 15, No. 2, pp. 181-188, 1992.

30. McInish, Thomas H. and Robert A. Wood, An Analysis of Intraday Patterns in Bid/Ask Spreads for NYSE Stocks, Journal of Finance, Vol. 47, No. 2, pp. 753-764, 1992.

31. Netter, Jeffry M. and Mark L. Mitchell, Stock-Repurchase Announcements and Insider Transactions after the October 1987 Stock Market Crash, Financial Management, Vol. 18, No. 3, pp. 84-96, 1989.

32. O'Hara, Maureen, Market Structure Theory, Blackwell Publishers, Cambridge, Massachusetts, 1995.

33. Pettitt, R. Richardson and P.C. Venkatesh, Insider Trading and Long-Run Return Performance, Financial Management, Vol. 24, No. 2, pp. 88-103, 1995. 
34. Raad, Elias and H.K. Wu, Insider Trading Effects on Stock Returns around Open-Market Stock Repurchase Announcements, Journal of Financial Research, Vol. 28, No. 1, pp. 45-57, 1995.

35. Seyhun, H. Nejit, Insider's Profits, Costs of Trading, and Market Efficiency, Journal of Financial Economics, Vol. 16, No. 2, pp. 189-212, 1986.

36. Sivakumar, Kumar and Gregory Waymire, Insider Trading Following Material News Events: Evidence From Earnings, Financial Management, Vol. 23, No. 1, pp. 23-32, 1994.

37. Stoll, Hans R., The Supply of Dealer Services in Securities Markets, Journal of Finance, Vol. 33, No. 4, pp. 1133-1151, 1978.

38. White, Halbert, A Heteroskedasticity-Consistent Covariance Matrix Estimator and a Direct Test of Heteroskedasticity, Econometrica, Vol. 48, No. 4, pp. 817-838, 1980. 